\title{
Akad Mudharabah Muthlaqah pada Deposito Kaffah di Bank Sumsel Babel Syariah
}

\author{
Dian Pertiwi \\ Universitas Islam Negeri Raden Fatah Palembang \\ pertiwi.dian_uin@radenfatah.ac.id
}

\begin{abstract}
Application of Mudharabah Muthlaqah on mudharabah deposits, the depositor or depositor acts as the owner of the funds (shahibul maal) and the bank acts as the manager of the funds (mudharib). The customer as the owner of the funds (shahibul maal) cannot provide certain limitations or requirements to the Islamic bank as the fund manager (mudharib) in managing their investment, whether related to the place, method or object of investment. Customers will get benefits in the form of profit sharing on deposits where the bank distributes profit sharing to customers with a ratio that has been agreed at the beginning and get results at maturity every month which goes directly to the customer's account. If there is a deposit payment before maturity, the bank will impose a fine on the customer in accordance with the bank's policy. Islamic banks have rights and freedoms in the mudharabah business. Profits from various sectors that are expected by Islamic banks to be profitable.
\end{abstract}

Key words: Mudharabah Muthlaqah, kaffah deposit, syariah banking

\begin{abstract}
Abstrak
Penerapan Mudharabah Muthlaqah pada deposito mudharabah, penyimpan atau deposan bertindak sebagai pemilik dana (shahibul maal) dan bank bertindak sebagai pengelola dana (mudharib). Nasabah sebagai pemilik dana (shahibul maal) tidak dapat memberikan Batasan atau persyaratan tertentu kepada bank Syariah sebagai pengelola dana (mudharib) dalam mengelola investasinya, baik berkaitan dengan tempat, cara maupun objek investasi. Nasabah akan mendapatkan manfaat berupa bagi hasil atas deposito yang dimilikinya dimana bank melakukan distribusi bagi hasil kepada nasabah dengan nisbah yang telah disepakati di awal dan mendapatkan bagi hasil pada waktu jatuh tempo atau setiap bulan yang langsung masuk ke rekening nasabah. Jika terjadi pencairan deposito sebelum jatuh tempo, maka bank akan mengenakan denda (penalty) kepada nasabah yang bersangkutan sesuai dengan kebijakan bank. Bank Syariah mempunyai hak dan kebebasan dalam menginvestasikan Mudharabah Muthlaqah ke berbagai sektor bisnis yang telah diperkirakan bank Syariah akan memperoleh keuntungan.
\end{abstract}

Kata kunci: Mudharabah Muthlaqah, deposito kaffah, perbankan syariah

\section{PENDAHULUAN}

Bank Syariah merupakan suatu sistem perbankan yang pelaksanaannya berdasarkan hukum Islam (Syariah). Pembentukan sistem Syariah ini berdasarkan larangan dalam agama Islam untuk meminjamkan atau manarik pinjaman dengan mengenakan bunga (riba), serta larangan untuk berinvestasi pada usaha yang bersifat haram. Berdasarkan Undang- 
Undang Nomor 21 Tahun 2008 tentang Perbankan Syariah, Bank Syariah adalah bank yang menjalankan kegiatan usahanya berdasarkan dengan prinsip Syariah atau prinsip hukum Islam yang diatur dalam fatwa Majelis Ulama Indonesia, seperti prinsip keadilan dan keseimbangan ('adl wa tawazun), kemaslahatan (maslahah), universalisme (alamiyah), serta tidak mengandung gharar, maysir, riba, zalim dan objek yang haram.

Dalam hal ini, kegiatan usaha yang dilakukan oleh Bank Syariah dan Bank Konvensional sangat berbeda. Bank Syariah tidak menerapkan sistem bunga, tetapi sistem untung dan rugi. Keuntungan dan kerugian yang terjadi akan ditanggung Bersama antara nasabah dan bank, sesuai dengan akad yang disepakati. Bank Syariah menggunakan prinsip Syariah yang merupakan aturan perjanjian berdasarkan hukum Islam antara bank dan pihak lain untuk penyimpanan dana, pembiayaan kegiatan usaha ataupun kegiatan lainnya yang dinyatakan sesuai dengan Syariah. Bank Syariah juga menggunakan prinsip bagi hasil (profit sharing) yang menjadi landasan utama dalam kegiatan operasional bank Syariah secara menyeluruh, secara Syariah prinsip tersebut berdasarkan akad mudharabah.

Dalam kegiatan operasional bank Syariah, mudharabah merupakan salah satu bentuk akad pembiayaan dalam transaksi bank yang akan diberikan kepada nasabahnya. Mudharabah merupakan akad Kerjasama usaha antara dua pihak, dimana pihak pertama menyediakan seluruh modah (shahibul maal), sedangkan pihak lainnya menjadi pengelola (mudharib). Keuntungan yang didapat dibagi menurut kesepakatan yang telah disepakati dan dituangkan di dalam kontrak (Syafi'i Antonio, 2001:95).

Dalam kontrak mudharabah, pengelola (mudharib) harus menjalankan kewajibannya dengan menjalankan usaha dengan sebaikbaiknya dan menentukan bentuk usaha yang tidak haram atau bertentangan dengan prinsip Syariah. Selain pembiayaan akad mudharabah juga diterapkan dalam penghimpunan dana, salah satunya yaitu deposito. Deposito merupakan simpanan berjangka dari pihak ketiga kepada bank dimana penarikannya hanya dapat dilakukan dalam jangka waktu tertentu berdasarkan akad perjanjian antara pihak ketiga dan bank.

Prinsip yang digunakan dalam penghimpunan dana di perbankan Syariah biasanya menggunakan akad wadiah yad dhamanah dan Mudharabah Muthlaqah. Produk di Bank Sumsel Babel Syariah yang menggunakan prinsip Mudharabah Muthlaqah adalah deposito kaffah.

Akad Mudharabah Muthlaqah adalah akad Kerjasama antara pemilik dana (shahibul maal) dan pengelola dana (mudharib) dan tidak ada Batasan bagi pengelola dana dalam menggunakan dana yang disimpan oleh pemilik dana. Dalam hal ini, Bank Sumsel Babel bertindak sebagai pengelola dana (mudharib) dan nasabah bertindak sebagai pemilik dana 
(shahibul maal). Dana tersebut digunakan oleh bank untuk melakukan kegiatan lainnya, seperti pembiayaan murabahah, sewa-menyewa (ijarah) maupun pembiayaan mudharabah. Dari hasil pengelolaan dana tersebut, bank akan memberikan bagi hasil kepada pemilik dana sesuai dengan nisbah yang telah disepakati di awal akad.

\section{KAJIAN LITERATUR}

\section{A. Mudharabah Muthlaqah}

Mudharabah Muthlaqah atau disebut juga dengan unrestricted mudharabah, merupakan bentuk Kerjasama antara pemilik dana (shahibul maal) dengan pengelola dana (mudharib) yang memberikan kebebasan kepada pengelola untuk mengelola dana dalam bentuk usaha apapun yang mendatangkan keuntungan selama usaha tersebut tidak bertentangan dengan prinsip syariah. Pada mudharabah muthalaqah ini, pemilik dana memberikan keleluasaan penuh kepada pengelola dana untuk mempergunakan dana tersebut dalam usaha yang menguntungkan dan tidak bertentangan dengan prinsip syariah. Namun pengelola tetap bertanggung jawab untuk melakukan pengelolaan dengan praktik kebiasaan usaha normal yang sehat.

Akad Mudharabah Muthlaqah digunakan untuk produk tabungan dan pembiayaan. Penerapan Mudharabah Muthlaqah pada produk tabungan berupa tabungan mudharabah dan deposito mudharabah. Dalam aplikasinya Mudharabah Muthlaqah, penyimpan atau deposan bertindak sebagai pemilik dana (shahibul maal) dan bank bertindak sebagai pengelola dana (mudharib). Pihak nasabah atau deposan yang menyimpan dananya di bank Syariah memberikan keleluasaan bagi pihak bank Syariah dalam menggunakan dana yang disimpan oleh nasabah, sehingga bank Syariah bebas untuk menetapkan akad seperti apa yang akan dipakai ketika menyalurkan pembiayaan, kepada siapa pembiayaan itu diberikan dan usaha apa yang bisa dibiayai oleh bank Syariah.

Ketentuan umum produk Mudharabah Muthlaqah, antara lain :

1. Bank sebagai pengelola dana (mudharib) wajib memberitahukan kepada pemilik dana (shahibul maal) mengenai nisbah dan tata cara pembagian keuntungan serta risiko yang dapat ditimbulkan dari penyimpanan dana. Apabila telah terjadi kesepakatan antara bank dan nasabah, maka hal tersebut harus dicantumkan dalam akad.

2. Untuk tabungan mudharabah, bank dapat memberikan buku tabungan sebagai bukti penyimpanan dan kartu ATM sebagai alat penarikan. Dan untuk deposito mudharabah, bank wajib memberikan sertifikat atau tanda penyimpanan (bilyet) deposito kepada deposan. 
3. Tabungan mudharabah dapat diambil setiap saat oleh penabung, sesuai dengan perjanjian yang telah disepakati namun tidak diperkenankan mengalami saldo negative

4. Deposito mudharabah hanya dapat dicairkan sesuai dengan jangka waktu yang telah disepakati. Deposito yang diperpanjang oleh deposan setelah jatuh tempo akan diperlakukan sama seperti deposito baru, tetapi apabila akad sudah dicantumkan perpanjangan deposito secara otomatis, maka tidak perlu dibuat akad baru.

Ketentuan lain yang berkaitan dengan tabungan dan deposito tetap berlaku jika tidak bertentangan dengan prinsip Syariah.

\section{B. Deposito Mudharabah Muthlaqah}

Deposito Mudharabah Muthlaqah, nasabah sebagai pemilik dana (shahibul maal) tidak dapat memberikan Batasan atau persyaratan tertentu kepada bank Syariah sebagai pengelola dana (mudharib) dalam mengelola investasinya, baik itu tempat, cara ataupun objek investasi. Bank Syariah memiliki hak dan kebebasan dalam menginvestasikan Mudharabah Muthlaqah ke berbagai sektor bisnis yang telah diperkirakan bank Syariah akan memperoleh keuntungan.

Pembayaran bagi hasil deposito Mudharabah Muthlaqah dapat dilakukan melalui dua metode, yaitu :

1. Anniversary Date (Tanggal Jadian)

a. Pembayaran bagi hasil deposito dilakukan secara bulanan, yaitu pada tanggal yang sama dengan tanggal pembukaan deposito;

b. Tingkat bagi hasil yang dibayarkan, yaitu tingkat bagi hasil tutup buku bulan terakhir;

c. Bagi hasil bulanan yang diterima nasabah dapat diafiliasikan ke rekening lainnya sesuai dengan permintaan deposan.

2. End of Month (Akhir Bulan)

a. Pembayaran bagi hasil deposito dilakukan secara bulanan, yaitu pada tanggal tutup buku setiap bulan

b. Bagi hasil bulan pertama dihitung secara proporsional hari efektif termasuk pada tanggal tutup buku, tetapi tidak termasuk pada tanggal pembukaan deposito

c. Bagi hasil bulan terakhir dihitung secara proporsional bulan efektif tidak termasuk pada tanggal jatuh tempo deposito. Tingkat bagi hasil yang dibayarkan, yaitu tingkat bagi hasil tutup buku pada bulan terakhir

d. Jumlah hari dalam sebulan adalah hari pada kalender bulan yang bersangkutan (28 hari, 29 hari 30 hari dan 31 hari). 
e. Bagi hasil bulanan yang diterima nasabah dapat diafiliasikan ke rekening lainnya sesuai permintaan deposan.

Pencairan deposito Mudharabah Muthlaqah dengan pembayaran bagi hasil bulanan yang dilakukan sebelum jatuh tempo, bank Syariah akan memberikan denda (penalty) kepada nasabah yang bersangkutan sesuai dengan kebijakan bank. Klausul denda harus ditulis dalam akad dan dijelaskan kepada nasabah pada saat pembukaan deposito Mudharabah Muthlaqah dengan jangka waktu 1,3,6 dan 12 bulan untuk disepakati bersama antara nasabah dan bank. Dalam hal ini, bagi hasil yang menjadi hak nasabah dan belum dibayarkan juga harus dibayarkan.

\section{Aplikasi Akad Mudharabah Muthlaqah pada Deposito Kaffah}

Nasabah sebagai pemilik dana (shahibul maal) dan bank sebagai pengelola dana (mudharib) secara bersama-sama disebut sebagai Para Pihak, dengan ini menerangkan hal-hal sebagai berikut:

1. Nasabah menyatakan menginvestasikan dananya kepada bank Syariah dengan prinsip mudharabah dalam bentuk rekening deposito kaffah yang berlaku sejak tanggal dibuka dan denan ini bank menyatakan bersedia mengelola dan mengadministrasikan rekening deposito kaffah atas nama nasabah.

2. Nasabah sebagai pemilik dana memberikan persetujuan kepada bank sebagai pengelola dana untuk mengelola dana nasabah serta diambil manfaatnya oleh bank sesuai dengan prinsip Mudharabah Muthlaqah tanpa Batasan apapun dan digunakan sesuai dengan prinsip syariah.

Nasabah dan bank dengan ini telah sepakat untuk mengadakan akad deposito kaffah berdasarkan ketentuan-ketentuan sebagai berikut:

\section{Pasal 1 Definisi:}

1. Akad adalah kesepakatan tertulis antara para pihak yaitu nasabah dan bank yang memuat hak dan kewajiban bagi masing-masing pihak sesuai dengan prinsip Syariah

2. Syariah adalah hukum Islam yang bersumber dari Al-Qur'an, Al-Sunnah dan/atau Fatwa Dewan Syariah Nasional

3. Deposito adalah investasi dana yang mana penarikannya hanya dapat dilakukan pada waktu-waktu tertentu berdasarkan akad antara nasabah dengan bank

4. Mudharabah adalah bentuk Kerjasama antara nasabah sebagai pemilik dana (shahibul maal) dan bank sebagai pengelola dana (mudharib) dengan membagi keuntungan usaha sesuai dengan kesepakatan yang dituangkan dalam akad 
5. Mudharabah Muthlaqah adalah prinsip mudharabah dimana nasabah memberikan keleluasaan penuh kepada bank untuk mempergunakan dana tersebut dalam usaha yang dianggap baik dan menguntungkan. Namun bank tetap bertanggung jawab untuk melakukan pengelolaan sesuai dengan praktik kebiasaan usaha normal yang sehat (uruf)

6. Deposito kaffah adalah produk bank berbentuk deposito, dimana nasabah menginvestasikan dananya pada bank berdasarkan prinsip Mudharabah Muthlaqah dengan nisbah bagi hasil dalam jumlah dan jangka waktu tertentu yang penarikannya hanya dapat dilakukan pada waktu tertentu menurut akad serta dapat dilakukan perpanjangan secara otomatis (Automatic Roll Over).

7. Nisbah bagi hasil adalah perbandingan (rasio) pembagian atas pendapatan yang dibagikan dari usaha Kerjasama antara nasabah dan bank yang ditetapkan berdasarkan akad ini

8. Jangka waktu adalah jangka waktu jatuh tempo pengembalian dana dan pembagian hasil usaha yang ditentukan berdasarkan kesepakatan para pihak.

9. Ketentuan umum dan persayaratan pembukaan rekening adalah suatu ketentuan dan persyaratan yang berlaku pada bank dan telah disepakati para pihak menjadi bagian satu kesatuan yang tidak terpisahkan dari akad ini.

\section{Pasal 2 Ketentuan Akad:}

1. Dalam hal kemungkinan terjadinya risiko kerugian dalam pengelolaan dana bukan disebabkan karena kesalahan bank, maka seluruh kerugian finansial ditanggung oleh nasabah, sedangkan kerugian non-finansial ditanggung oleh bank.

2. Bank menutup biaya operasional pengelolaan dana menggunakan nisbah keuntungan yang menjadi haknya.

3. Bank tidak diperkenankan mengurangi nisbah keuntungan nasabah tanpa persetujuan yang bersangkutan.

\section{Pasal 3 Jangka Waktu:}

1. Jangka waktu akad deposito kaffah adalah ... .bulan, terhitung sejak tanggal ....

2. Para pihak sepakat bahwa jangka waktu dalam ayat (1) pasal ini secara otomatis berlaku Automatic Roll Over (ARO) guna diperpanjang untuk periode yang sama

3. Dalam hal nasabah ingin menghentikan Automatic Roll Over (ARO) pada bulan berikutnya, maka wajib melakukan 
konfirmasi pengakhiran Automatic Roll Over (ARO) kepada bank.

\section{Pasal 4 Nisbah Bagi Hasil:}

1. Nasabah dan bank sepakat untuk berbagi hasil atas keuntungan yang diperoleh dari pengelolaan dana tersebut, dengan nisbah bagi hasil untuk nasabah sebesar...... persen

2. dan untuk bank sebesar persen.

3. Bagi hasil dihitung sesuai dengan hasil perhitungan bank dan didistribusikan sampai dengan ulang tanggal dengan mempergunakan hasil perhitungan bank pada satu bulan sebelumnya.

4. Pajak atas bagi hasil yang diperoleh nasabah ditanggung oleh nasabah sesuai ketentuan yang berlaku.

5. Bila terjadi perubahan nisbah, akan diinformasikan pada papan pengumuman di Kantor Pusat Unit Usaha Syariah, Kantor Cabang, Kantor Cabang Pembantu dan Kantor Kas Bank Sumsel Babel Syariah.

6. Apabila dalam lima hari kerja setelah tanggal pengumuman tersebut tidak ada konfirmasi dari nasabah, maka nasabah dianggap menyetujui perubahan nisbah tersebut.

\section{Pasal 5 Pencairan/Penarikan:}

1. Pencairan dana dilakukan dengan menyerahkan bilyet deposito asli

2. Apabila nasabah tidak dapat melakukan pencairan dana deposito secara langsung, dapat digantikan pihak lain dengan menyerahkan surat kuasa dan bilyet deposito setelah mendapatkan persetujuan dari bank

3. Dalam hal nasabah melakukan pencairan dana sebelum jangka waktu akad berakhir, maka bank berhak untuk tidak membayar bagi hasil periode yang bersangkutan serta mengenakan denda sesuai ketentuan yang berlaku pada bank.

\section{Pasal 6 Kewajiban:}

1. Bank

a. Bank akan menerbitkan bilyet deposito kaffah pada pembukaan rekening yang diterbitkan atas nama nasabah tersebut sebagai bukti kepemilikan deposito

b. Bank memberikan bagi hasil kepada nasabah sesuai dengan nisbah yang telah disepakati para pihak

c. Dalam hal deposito kaffah diperpanjang secara Automatic Roll Over (ARO), maka bank akan menuliskan dibelakang 
bolyet deposito tanggal akad dan nisbah bagi hasi, pada saat deposan dating ke cabang penerbit. Perpanjangan secara Automatic Roll Over (ARO) tersebut tanpa menerbitkan bilyet deposito baru

2. Nasabah

a. Nasabah berkewajiban untuk menyerahkan dokumen berupa fotokopi Kartu Tanda Penduduk/Surat Izin Mengemudi/Nomor Pokok Wajib Pajak. Paspor Identitas lainnya yang masih berlaku pada saat pembukaan rekening dan berkewajiban untuk segera menginformasikan kepada bank jika terdapat perubahan dokumen dimaksud selama jangka waktu akad.

b. Nasabah berkewajiban untuk menyetor dana sebesar yang tercantum dalam bilyet deposito

c. Nasabah berkewajiban untuk membayar biaya administrasi sesuai ketentuan yang berlaku pada bank

d. Jika kartu bilyet deposito hilang, maka nasabah berkewajiban untuk memberitahukan secara tertulis kepada bank dengan menyebutkan nomornya dan melampirkan surat keterangan kehilangan dari pihak kepolisian setempat.

\section{Pasal 7 Penutupan Rekening:}

1. Bank diberi hak untuk menutup deposito apabila :

a. Rekening nasabah telah jatuh tempo

b. Nasabah meninggal dunia dan saldo rekening diserahkan kepada ahli waris atau yang ditunjuk oleh ahli waris setelah menyerahkan bilyet deposito dan fatwa waris

c. Menurut bank pertimbangan perlu dilakukan berdasarkan ketentuan perundang- undangan.

2. Apabila penutupan rekening dilakukan oleh nasabah sebelum jatuh tempo, bank berhak untuk tidak membayar bagi hasil deposito periode yang bersangkutan serta membebankan biaya administrasi bukan sebagai denda (ta'zir) sebesar ketentuan yang berlaku pada bank.

\section{Pasal 8 Lain lain:}

1. Nasabah dengan ini memberikan persetujuan kepada bank untuk memberikan data atau informasi nasabah kepada pihak lain dalam rangka menjalankan suatu ketentuan peraturan perundang-undangan dan/atau menjalankan suatu kegiatan promosi/tujuan komersial lainnya dan/atau sebagau akibat timbulnya haka tau kewajiban para pihak atas pelaksanaan ketentuan dan persyaratan deposito kaffah. Nasabah dengan ini 
membebaskan bank dari segala tuntutan yang timbul akibat pemberian dan/atau diterimanya data-data tersebut.

2. Segala sesuatu yang belum diatur atau perubahan dalam akan ini akan diatur dalam surat-menyurat atau addendum berdasarkan kesepakatan bersama antara para pihak yang merupakan bagian yang tidak terpisahkan dari akad ini

3. Semua pemberitahuan tertulis dari bank dan semua surat menyurat antara para pihak dalam pelaksanaan akad ini mengikat dan harus ditaati oleh nasabah

4. Pelaksanaan akad ini tunduk kepada ketentuan perundangundangan dan ketentuan Syariah yang berlaku bagi bank di Indonesia

5. Apabila dikemudian hari terjadi perselisihan dalam penafsiran atau pelaksanaan ketentuan-ketentuan dari akad ini, maka para pihak sepakat untuk terlebih dahulu menyelesaikan secara musyawarah

6. Bilamana musyawarah tidak menghasilkan kata sepakat mengenai penyelesaian perselisiham, maka para pihak sepakat untuk memilih tempat kedudukan hukum (domisili) yang tetap di Kantor Pengadilan Agama setempat sesuai dengan domisili cabang pembuka rekening

7. Uraian pasal demi pasal dalam akad ini dan ketentuan umum dan persyaratan pembukaan rekening, telah dibaca, dimengerti dan dipahami serta disetujui oleh para pihak

8. Akad ini mulai berlaku sejak tanggal ditandatangani.

\section{Syarat dan Ketentuan Produk Deposito Kaffah}

1. Dana simpanan berdasarkan prinsip Syariah dengan akad Mudharabah Muthlaqah

2. Dana yang disetorkan harus tunai bukan piutang

3. Bagi hasil atas deposito kaffah dibayarkan pada setiap bulan atau pada saat jatuh tempo

4. Setoran pertama per bilyet minimal Rp. 1.000.000,-

5. Biaya materai

6. Nasabah memiliki rekening tabungan untuk penampungan bagi hasil deposito

7. Nasabah mengisi formulir pembukaan deposito kaffah

8. Menyerahkan fotokopi KTP dan Kartu Keluarga. 
E. Nisbah yang ditaearkan Bank Sumsel Babel Syariah

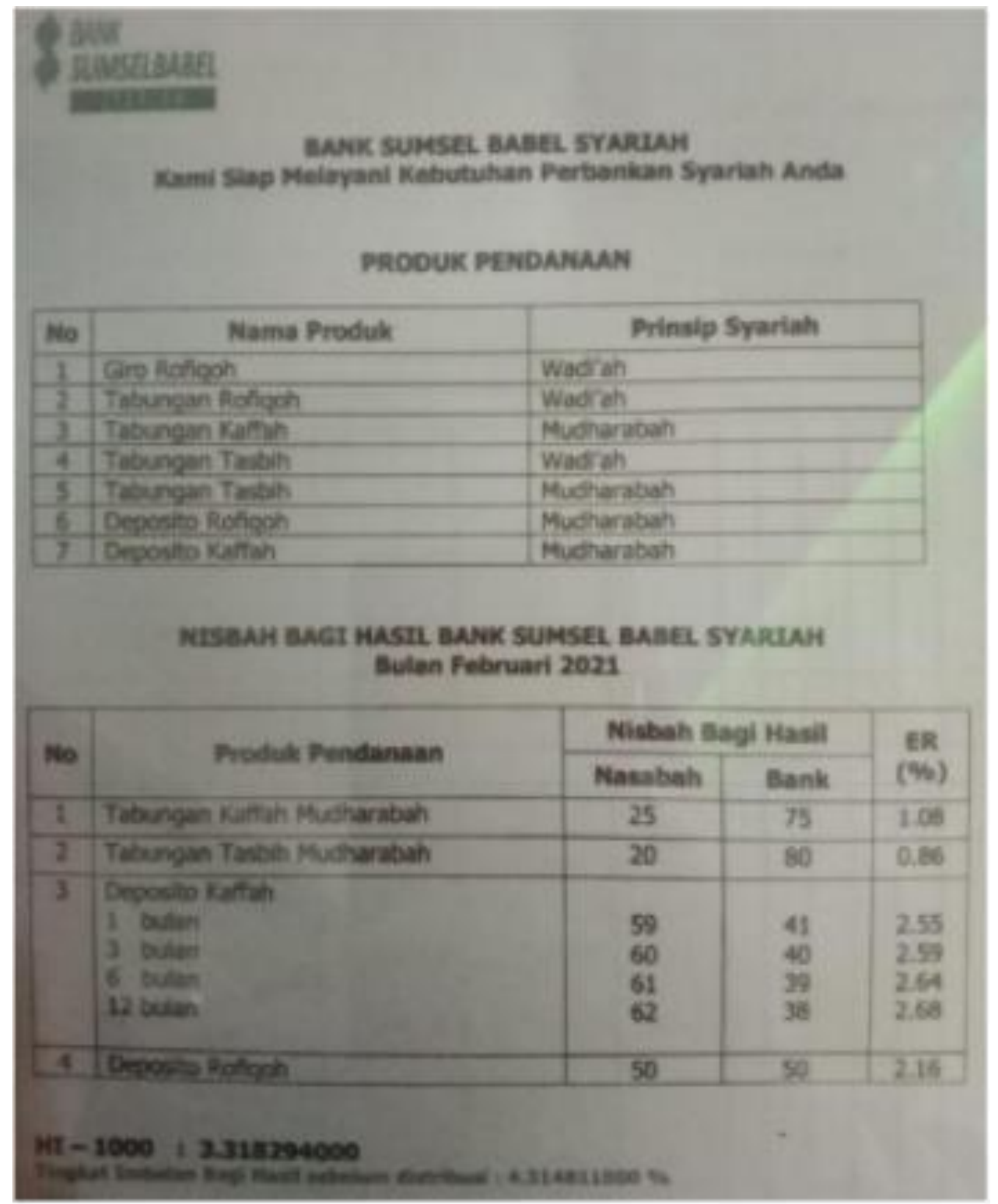

Gambar 1. Nisbah Bagi Hasil Bank Sumsel Babel Syariah Februari 2021

\section{KESIMPULAN}

Mudharabah Muthlaqah merupakan bentuk Kerjasama antara pemilik dana (shahibul maal) dengan pengelola dana (mudharib) yang memberikan kebebasan kepada pengelola untuk mengelola dana dalam bentuk usaha apapun yang mendatangkan keuntungan selama usaha tersebut tidak bertentangan dengan prinsip Syariah. Namun pengelola tetap bertanggung jawab untuk melakukan pengelolaan sesuai dengan praktik kebiasaan usaha normal yang sehat (uruf). 
Dalam dunia perbankan, penerapan Mudharabah Muthlaqah pada deposito mudharabah, penyimpan atau deposan bertindak sebagai pemilik dana (shahibul maal) dan bank bertindak sebagai pengelola dana (mudharib). Nasabah sebagai pemilik dana (shahibul maal) tidak dapat memberikan Batasan atau persyaratan tertentu kepada bank Syariah sebagai pengelola dana (mudharib) dalam mengelola investasinya, baik berkaitan dengan tempat, cara maupun objek investasi. Bank Syariah mempunyai hak dan kebebasan dalam menginvestasikan Mudharabah Muthlaqah ke berbagai sektor bisnis yang telah diperkirakan bank Syariah akan memperoleh keuntungan.

Produk deposito kaffah dengan akad mudharabah muthalaqoh di Bank Sumsel Babel Syariah sudah sesuai dengan prinsip Syariah. Dana deposito kaffah ditempatkan oleh nasabah/deposan pada Bank Sumsel Babel Syariah yang tidak bertentangan dengan prinsip Syariah. Nisbah bagi hasil juga sudah sesuai denan akad perjanjian yang telah disepakati di awal antara bank dan nasabah. Penyaluran dana juga diberikan dalam produk pembiayaan

Nasabah akan mendapatkan manfaat berupa bagi hasil atas deposito yang dimilikinya dimana bank melakukan distribusi bagi hasil kepada nasabah dengan nisbah yang telah disepakati di awal dan mendapatkan bagi hasil pada waktu jatuh tempo atau setiap bulan yang langsung masuk ke rekening nasabah. Jika terjadi pencairan deposito sebelum jatuh tempo, maka bank akan mengenakan denda (penalty) kepada nasabah yang bersangkutan sesuai dengan kebijakan bank.

\section{DAFTAR PUSTAKA}

Antonio, Muhammad Syafi'I, 2001, Bank Syariah: Dari Teori ke Praktik, Jakarta : Gema Insani

Departemen Pendidikan Nasional, 2002, Kamus Besar Bahasa Indonesia, Jakarta: Balai Pustaka, 2002.

Karim, Adiwarman. 2004, Bank Islam : Analisis Fikih dan Keuangan, Jakarta: RajaGrafindo Persada

Mardani. 2012. Fiqh Ekonomi Syariah. Jakarta : Kencana

M. Abdul Majdid dkk, 1994, Kamus Istilah Fikih, Jakarta: Pustaka Firdaus.

Sahroni, Oni. 2017. Ushul Fikih Muamalah : Kaidah-Kaidah Ijtihad dan Fatwa dalam Ekonomi Islam. Depok: Rajawali Pers

Suhendi, Hendi. 2010. Fiqh Muamalah. Jakarta : Rajawali Pers

Susamto, Burhanuddin, 2009, Hukum Kontrak Syariah, Yogyakarta : BPFEYogyakarta

TM. Hasbi Ash Shiddieqy, 1990, Hukum-Hukum Fiqih Islam, Yogyakarta: PT. Rosda Karya,Cet. 2. 